\title{
The Role Professional Accountant Firms play within the Liberian Market in Terms of Strategic Implementation of Financial Statement Audit
}

\author{
Jerome M. Kesselly \\ College of Business and Management, Texila American University, Monrovia, Liberia
}

\begin{abstract}
The study has evaluated the role Professional Accountant Firms play in the Liberian market and to understand the strategic tools used in implementing financial statement Audits [1]. A deductive approach was adopted, and information was collected from thirty respondents via Unstructured faceto-face interviews. Purposive sampling was engaged as this technique aided the cognizant arrangement of targeted respondents (Audit Associates, Staff Auditors, Semi Senior Auditors, Senior Auditors, Asst. Audit managers, Audit Managers, and Audit Partners). The findings show that Professional Accountant Firms in Liberia play a positive and significant role in the Liberian market. Professional Accountant Firms make great contributions in keeping Liberian businesses at full compliant with international financial reporting standards, legal and regulatory requirements, and their own policies and procedures. It is recommended that to be more efficient, Liberian businesses should embrace the role Professional Accountant Firms play within the Liberian market. It is concluded that the Liberia Institute of certified Public Accountants (LICPA) should strengthen, trained, and Licensed all Professional Accountant Firms to meet the growing need of the Professional Accounting industry in the Country.
\end{abstract}

Keywords: Professional Accounting Industry, Financial Statement, Reporting Standards, Liberian Businesses.

\section{Introduction}

The role professional accountants play in business is to examine the quality of financial reporting. [2] It is the management's responsibility for the financial information. Like their counterparts in taxation or auditing, professional accountants in business play important roles that contribute to the overall stability and progress of society. Without a public understanding of all these diverging roles and responsibilities of different accounting specialists working in business, public perceptions of their value may be misinformed.

Accountants are trained in the theory and practice of accounting and in the Analysis and evaluation of the company's business accounts through an Audit. Accountants typically evaluate annual reports, other periodic reports, and financial statements for planning, decisionmaking purposes, and investment opportunities. Accountants performed an independent examination of evidence from which the financial statements of a business or other entities are derived in order to give the reader of such financial statement's confidence as to the truthfulness and fair presentation of the affairs of the entity as disclosed in the financial statements [3].

Professional Accountants in Liberia are authorized by a statutory body, the Liberia Institute of Certified Public Accountants (LICPA) in the country to practice as individual, or as a firm, holding a practicing Licensed. The institute is the accounting standard-setting body 
in Liberia, established by an Act. The act was established by the institute to represent, promote, and regulate the accountancy profession in Liberia, in the public interest [4].

\section{Methodology}

In this study, both primary and secondary data were collected and analyzed. An unstructured questionnaire was developed to collect responses from professional accountants working in various professional firms within Liberia, precisely Monrovia. Also, face to face meetings was held with Audit Associates, Staff Auditors, Semi Senior Auditors, Senior Auditors, Assistant Audit managers, Audit Managers, and Audit Partners from different Professional Accountant Firms in Liberia, Baker Tilly Liberia, BICON, Inc., Deon, and Noed International (DnI) Liberia LLC, Farhat Carew Inc., Pan African Consultants, Parker \& Co., LLC, PKF-Liberia, PricewaterhouseCoopers Liberia (PwC), Seekie \& Associates, SovConsult Limited, T. D. Joseph \& Associates (now Crowe Liberia LLC), MGI-Monbo \& Company, and Gedei \& Associates [5]. All the respondents from those firms were asked questions at their level within their respective firms. Regarding the secondary, data were collected from the Liberia Institute of Certified Public Accountants Official site [6].

Based on the data collected and analyses to define the conclusion of the topic, hereafter, this study has been presented by using a qualitative approach with an emphasis on interview report analysis to derive the qualitative result. The qualitative study is anchored on the distinct understanding of the methodological traditions of enquiry that evaluate social or human issues. The qualitative study work postulates an empirical view by understanding social issues to describe and understand human behavior (Timmermans, S. Tavory, I (2012) [7].

\section{Literature Review}

The idea of professional accountancy came about when petitioners were induced to form themselves into a Society called the Institute of Accountants in Edinburgh, with a view to unite into one body, those at present practicing the profession, and to promote the objects which they entertain in common; and that the Petitioners conceive that it would tend to secure in the members of the profession, the qualifications which are essential to the proper performance of its duties, and would consequently conduce much to the benefit of the public [8]. Today, Competent professional accountants now become a valuable asset to Accounting firms, their working is based on their knowledge of various company's financial statements, Audit, and advisory services. Using their skills and intimate understanding of companies and their control environment. Their training in accounting and Auditing enables them to adopt a pragmatic and objective approach to solving issues, provide advice, and help businesses to strengthen their internal controls in order to prevent losses. Professional accountants represent the interest of their firms. Their roles ordinarily include investigating financial statements for errors and fraud, performing audits on operations, and reporting on findings, and expressing opinions on Audit Reports [9].

\section{The Credibility of Professional Accountant Firms}

The services provided by Professional Accountant Firms in the country is to have an independent view express an opinion on an institution's financial statements [10]. The professional Accountant assesses whether the financial statements are prepared, in all material respects, in accordance with an applicable financial reporting framework and whether they present fairly the financial position of an organization. They serve as a framework for credible and high-quality professional accountancy organizations focused on serving the public interest by adopting, or otherwise incorporating, and supporting the 
implementation of international standards and maintaining adequate enforcement mechanisms to ensure the professional behavior of their individual members [11].

\section{Education and Certification Capacity for Professional Accountants}

Professional Accountant firms in Liberia need systems of certification that include appropriate entry criteria, professional accountancy education, assessment, practical experience, and continuing professional development (CPD) requirements in line with International Education Standards (IESs) [12]. Although many professional accountant firms in Liberia have made significant gains in this area, additional assistance is needed to target weaknesses, build human capacity in the area of accountancy, and provide higher quality in performing financial statement Audits for both public and private sectors.

Those assistances could also help support the creation of formal systems to undertake the process of translating and incorporating updates to international standards on a timely basis. Additionally, those supports should be directed toward the design, development, and operation of the systems of certification, quality assurance, oversight, investigation, and discipline will further the implementation of international standards and enhance the realization of their benefits, both the firms and clients within Liberia.

\section{Further Implementation of International Standards by professional Accountant firms in Liberia}

Although many businesses in Liberia have adopted international accountancy standards through the LICPA (e.g., International Standards of Auditing, International Financial Reporting Standards, International Public Sector Accounting Standards, and the Code of Ethics for Professional Accountants), the inappropriate modification of standards by many businesses in Liberia may cause serious deficiencies in the application of standards and may reduce their international comparability, consistency, and cross-border understanding.

Experience has shown that a solid understanding of the following standards is essential when auditing client's financial statements. (See Table 1).

Table 1. Audit process as per ISA Standard

\begin{tabular}{|l|l|}
\hline Code & Standards \\
\hline ISA 200 & Audit Planning \\
\hline ISA 230 & Audit Documentation \\
\hline ISA 240 & $\begin{array}{l}\text { Auditor's Responsibilities Relating to Fraud in an Audit of Financial } \\
\text { Statements }\end{array}$ \\
\hline ISA 250 & Consideration of Laws and Regulations in an Audit of Financial Statements \\
\hline ISA 260 & Communication with those Charged with Governance \\
\hline ISA 265 & $\begin{array}{l}\text { Communicating Deficiencies in Internal Control to Those Charged with } \\
\text { Governance }\end{array}$ \\
\hline ISA 300 & Audit Risk Assessment \\
\hline ISA 315 & $\begin{array}{l}\text { Identifying and Assessing the Risks of Material Misstatement Through } \\
\text { Understanding the Entity and its Environment }\end{array}$ \\
\hline ISA 330 & The Auditor's Responses to Assessed Risks \\
\hline ISA 320 & Materiality in Planning and Performing an Audit \\
\hline ISA 620 & Using the Work of an Auditor's Expert \\
\hline ISA 700 & Forming an Opinion on the Financial Statements \\
\hline
\end{tabular}


The Work of a Professional Accountant Firm in Liberia is Guided by Professional Standards

International Standards of Auditing (ISA) are widely recognized as high-quality standards for the performance of audits of financial information by professional Accountants firms in Liberia. They are issued by the International Auditing and Assurance Standards Board (IAASB), and most jurisdictions use ISA as their national or benchmark norms for auditing.

In July 2015, the Governing Council of the Liberia Institute of Certified Public Accountant (LICPA) issued Regulation 1: Professional Standards and Related Practice Statements that, among other things, adopted International Financial Reporting Standards (IFRS) as the accounting framework in Liberia effective 31 December 2018, with earlier application encouraged. (The effective date of Regulation 1 was initially 31 December 2016, but the LICPA subsequently amended that to 31 December 2018.) [13].

Public Perception of the Role of Professional Accountant Firms in Liberia

Sections 8, 9, and 16 of the LICPA Act stipulate that the LICPA is responsible for the adoption of ethical requirements and that the Code of Professional Ethics is appropriately responsive to the needs of stakeholders that rely on the work of accountants. Furthermore, Section 16 stipulates that LICPA should be in compliance with the requirements of IFAC's SMO 4 relating to the adoption of the IESBA Code of Ethics. This is a concern with the degree of responsibility for detecting fraud, legal irregularities, and other matters that are not within the financial reporting area [14]. In the Liberian context, the expectation gap can also relate to assurances on the effectiveness of LICPA regulations. An unmodified audit report may be mistakenly perceived as a clean bill of health to businesses in the country. Under ISA, however, Professional Accountant firms express their opinion only on whether the financial statements are prepared, in all material respects, in accordance with the applicable accounting framework. While a report on internal controls (i.e., a management letter) may also be provided, the professional Accountant firms are concerned with fraud and control weaknesses that cause a material misstatement in the financial statements [15].

\section{Professional Accountant Firms Approach to Executing an Audit Engagement}

Most of the professional Accountant firm's approach is top-down and risk-based, emphasizing planning and a thorough understanding of client operations, that is to Identify and test controls intended to address the risks of material misstatement; Test the design and effectiveness of management review controls; Obtain evidence needed to update test results on controls in the roll-forward period; Test controls on data and reports that themselves to support other important controls, and Sufficiently evaluate control deficiencies [16].

\section{Result and Discussions}

There were thirty-two (30) respondents that partake in this study. Audit Associates, Staff Auditors, Semi Senior Auditors, Senior Auditors, Assistant Audit managers, Audit Managers, and Audit Partners from different Professional Accountant Firms in Liberia were interviewed (See Table 2). The questionnaire was tailored as per different levels within the Professional Accountant firms. During our discussion with the respondents, they pointed out how important their roles are within the industry in turn of financial statement Audit and how effective their recommendations have help strengthen businesses in the country. 
Table 2. List of Respondents and Firms

\begin{tabular}{|l|l|l|l|}
\hline Firm Name & Position & $\begin{array}{l}\text { Year of } \\
\text { Experience }\end{array}$ & $\begin{array}{l}\text { Number of } \\
\text { Respondents }\end{array}$ \\
\hline Baker Tilly Liberia & Audit Managers & $7-10 \mathrm{yrs}$ & 2 \\
\hline BICON, Inc. & Audit Seniors & $5-6 \mathrm{yrs}$ & 5 \\
\hline $\begin{array}{l}\text { Deon and Noed International (DnI) } \\
\text { Liberia LLC }\end{array}$ & Audit Seniors & $4-6 \mathrm{yrs}$ & 3 \\
\hline Farhat Carew Inc. & Audit Associates I\&II & $1-2 \mathrm{yrs}$ & 4 \\
\hline Pan African Consultants & Audit Associates I\&II & $1-2 \mathrm{yrs}$ & 3 \\
\hline Parker \& Co. LLC & Asst. Audit Managers & $5-7 \mathrm{Yrs}$ & 2 \\
\hline PricewaterhouseCoopers Liberia (PwC) & Audit Partners & $10 \mathrm{yrs}$ & 2 \\
\hline Seekie \& Associates & Audit Seniors & $4-6 \mathrm{yrs}$ & 1 \\
\hline SovConsult Limited & Semi Senior Auditor & $4-6 \mathrm{yrs}$ & 1 \\
\hline $\begin{array}{l}\text { T. D. Joseph \& Associates (now Crowe } \\
\text { Liberia LLC), }\end{array}$ & Asst. Audit Managers & $5-7 \mathrm{Yrs}$ & 3 \\
\hline MGI-Monbo \& Company & Staff Auditors & 2-4yrs & 3 \\
\hline Gedei \& Associates & Audit Seniors & $4-6 \mathrm{yrs}$ & 1 \\
\hline Total Respondents & & $\mathbf{3 0}$ \\
\hline
\end{tabular}

Source: Field data report (Oct. 2021)

\section{Discussion on the Role Professional Accountant Firms Play in Liberia}

$90 \%$ of the respondents find the profession unique. They stated that the best place to start a career in the profession is at a professional accountant firm. According to the Audit Manager at Baker Tilly Liberia, the firm recruits young accountants from universities and trains them to become professional accountants by given them the opportunity to participate in professional exams and attend professional Auditing webinars. He further stated that the firm is responsible for financing the Audit staff professional exams and webinars as a way of capacity building for Liberian working at various accountant firms to be more efficient and effective during the Audit engagement. 98\% also claimed that the accountant firms are hired by businesses in the country to review and audit their financial statements. According to Sarah Ovaska, becoming a professional accountant takes intention and effort, but the rewards for joining the profession known for its trustworthiness and rigor are numerous for those who meet the requirements [17].

\section{Discussion on the Implementation Process of Financial Statement Audit}

According to the Audit Senior at Crowe Liberia, when the firm is successful in winning an audit engagement contract from a client, an engagement letter is prepared and send to the client to execute the Audit. In executing an Audit engagement, the firm goes through the four stages of the Audit process: Plan the Audit; a pre Audit questionnaire (survey or preliminary review questions) is prepared, this process is performed to assess the risks of the client entity, and it environment; perform fieldwork, before carrying out the fieldwork, the Audit team holds an entry meeting with the client in order to understand the client operations, carryout test of controls and substantive testing procedures to ascertain whether there were fraud or control weaknesses within the client's organization that cause a material misstatement in the financial statements; reporting, during the reporting stage of the audit engagement, management letter is provided to the client highlighting issues that are a risk to the organization and issue of best practice. The last stage of the Audit process is 
the follow-up, where previous Audit recommendations are reviewed based on changes made in status (e.g., Implemented; not implemented; ongoing). [17]

\section{Recommendation}

It is critically important to for professional Accountant firms to incorporate more females into the profession in order to reduce the gender gaps. To do that, professional accountant firms should change their strategy by approaching universities in the country and pinpointing potential females majoring in accounting in their early junior year and offering them internship opportunities to develop a passion for the profession by becoming Audit managers and partners. It is recommended that for better decision making by business owners, there is a need to have professional accountant firms to review and investigate businesses financial information for prompt decision-making thus performing Financial Statements Audit as essential to business enterprise in the country.

\section{Conclusion}

It is imperative clearer for businesses to adopt the use of having professional Accountant firms in the country to review and investigate their financial information's in order for prompt management decision making. It is becoming increasingly crucial for professional accountant firms to focus more on training and developing young female accountants to be more effective and efficient in performing full Audit engagement. A financial statement audit is the examination of business financial statements and accompanying disclosures by an independent auditor (professional Accountant Firm). The result of the examination is a report by the auditor attesting to the fairness of the presentation of the financial statements and related disclosures. It can also be used to add credibility to the reported financial position and performance of businesses in the country.

Table 3 below highlights that the selected population has enough experience in financial Statement Audit, of which 23\% has up to ten years' experience and serving in the position of Audit managers with the ability to managed more than five to six Audit Engagements at the same time. It also shows that there is enough Audit managers working at various professional Accountant firms in Liberia.

Table 3. Year of Experience

\begin{tabular}{|l|l|l|l|}
\hline \# Of Respondents & Year of Experience & Age Group & $\mathbf{\%}$ \\
\hline 7 & $1-2 \mathrm{yrs}$ & $18-25 \mathrm{Yrs}$ & $23 \%$ \\
\hline 3 & $2-4 \mathrm{yrs}$ & $30-35 Y r s$ & $10 \%$ \\
\hline 11 & $4-6 \mathrm{yrs}$ & $36-45 Y r s$ & $37 \%$ \\
\hline 7 & $7-10 \mathrm{yrs}$ & $46-50 Y r s$ & $23 \%$ \\
\hline 2 & 10 yrs. above & 50 and Above Yrs. & $7 \%$ \\
\hline
\end{tabular}

Sources: Field data report (Oct. 2021)

Figure 1 below of this study indicates that $77 \%$ of the respondents from the various professional accountant firms were male, and
$23 \%$ were female. Hence, this is evident that there are gender gaps within the professional accountant firm in Liberia (Field data). 


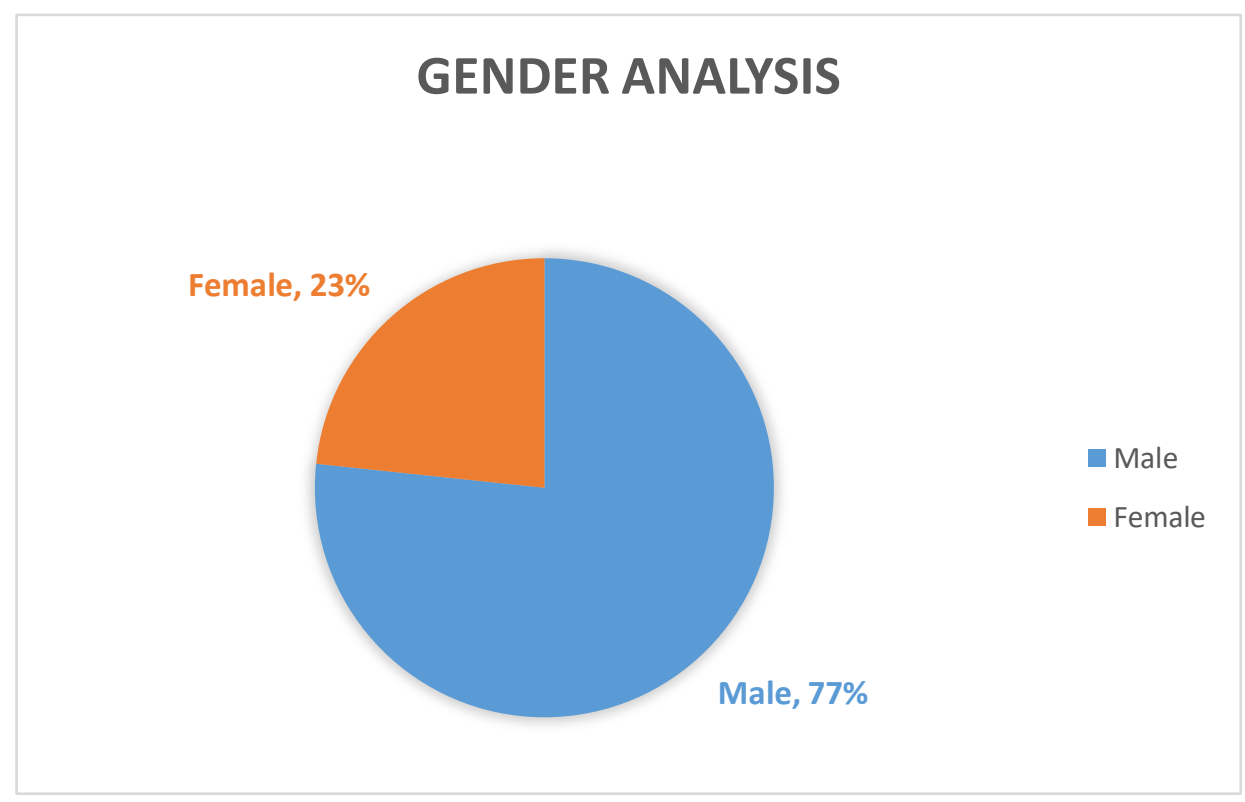

Figure 1. Respondents by Gender group

Sources: Field data report (Oct. 2021)

Figure 2 below shows that $37 \%$ of the overall population of professional accountants between the age 36 to $45 y$ rs of age hold Senior Auditor positions in professional Accountant firms in
Liberia. The data collected shows that most of these respondents are from an accounting background.

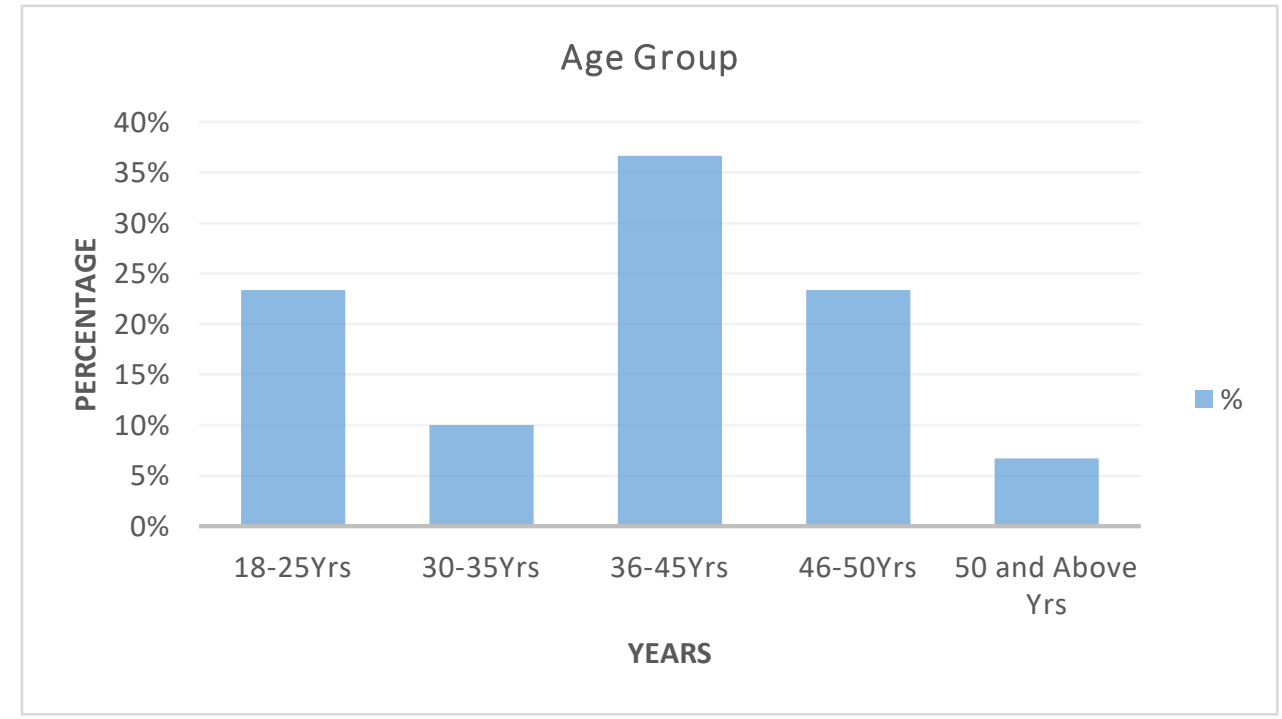

Figure 2. Respondents by Age Group

Sources: Field data report (Oct. 2021)

\section{Conflicts of Interest Statement}

This paper Title: The Role Professional Accountant Firms play within the Liberian Market in terms of strategic implementation of Financial Statement Audit.
The author, whose name is mentioned immediately below, certified that he has NO affiliation with or involvement in any institution with the financial interest, such as honoraria; educational grant; employment; or non-financial interest such as personal or professional 
relationship, affiliations in the subject matter, or materials discussed in this paper.

\section{Acknowledgment}

The Author of this research would like to take this time to thank the Almighty for giving him

\section{References}

[1] Teri Saylor, 2020. Developing a strategic audit plan Retrieved From:

https://www.journalofaccountancy.com/newsletters/

2020/nov/developing-strategic-audit-plan.html.

[2] Len Jui, CPA, MBA, and Jessie Wong, CPA, Ph.D., 2013, Roles and Importance of Professional Accountants in Business Retrieved From: https://www.ifac.org/about-ifac/professionalaccountants-business/news-events/2013-10/rolesand-importance-professional-accountants-business.

[3] Wiki Accounting, Management Responsibilities on Financial Statements Retrieved From https://www. wikiaccounting.com/managementresponsibilities-on-financial-statements/.

[4] The LICPA Act (2011) P 25-26 Retrieved From: https://www.moci.gov.lr/doc/Certified\%20Public\%2 0Accountants.pdf.

[5] The LICPA Member Firm Retrieved From: https://licpa.org.lr/index.php/firm-membership/.

[6] The LICPA Official Site Retrieved From: https://licpa.org.lr/index.php/downloads/.

[7] Timmermans, S. Tavory, I. (2012). Theory construction in Qualitative Research Retrieved From grounded theory. To abductive Analysis sociological theory, $\quad 30, \quad 167-186 . \quad$ Googles scholar/sage/journal/ISI.

[8] Institute of Chartered Accountants of Scotland, Royal Charter of 1854 and Supplementary Charter of 1951, Scotland: ICAS, 1854 and 1951, accessed, 2013 Retrieved From:

http://icas.org.uk/CharterRulesRegulationsafter10July/.

[9] AS 2810, Evaluating Audit Results Retrieved From:

https://pcaobus.org/oversight/standards/auditingstandards/details/AS2810. the strength and knowledge in doing this work. And the staff of various Professional Accountant firms in Monrovia in helping with all the necessary pieces of information for the success of this study.

[10] Kimberlee Leonard, 2019. What Services Are Provided by Accounting Firms Retrieved From: https://smallbusiness.chron.com/services-providedaccounting-firms-62323.html.

[11]IFAC Report, 2020. the credibility of professional accountant firm Retrieved From https://www.ifac.org/aboutifac/membership/members/liberian-institutecertified-public-accountants.

[12] IAESB Report, 2018, P4 Retrieved From: https://www.ifac.org/system/files/publications/files/I AESB-International-Education-Standard-7_0.pdf.

[13]Regulation 1 IFRS, 2018 Retrieved From: https://www.ifrs.org/use-around-the-world/use-ofifrs-standards-by-jurisdiction/viewjurisdiction/liberia/.

[14] The LICPA Act, 2011 Sections 8, 9, and 16 Retrieved

From: https://www.moci.gov.lr/doc/Certified\%20Public\%2 0Accountants.pdf.

[15] ISA 700 (revised), forming an opinion and reporting on financial statements Paragraphs 25-26 deal with the phrases used to express this opinion in the case of a fair presentation framework and a compliance framework, respectively. Retrieved From:

https://www.ifac.org/system/files/publications/files/I SA-700-Revised_8.pdf.

[16]Resolver official Site Retrieved From: https://www.resolver.com/resource/developing-atop-down-risk-based-approach-to-sox.

[17]Sarah Ovaska (2021) Retrieved From: https://www.journalofaccountancy.com/news/2021/n ov/bright-future-young-cpas.html. 